\title{
The Role of a Development Agency in Peacebuilding: Track One-and-a-Half Mediation in Mindanao
}

\author{
Sachiko Ishikawa
}

\begin{abstract}
Japan's development assistance to conflict-affected areas in Mindanao, southern Philippines, opened new pathways for the Japan International Cooperation Agency (JICA) to support multilateral peacebuilding efforts. JICA, in collaboration with Universiti Sains Malaysia, organized a series of Consolidation for Peace Seminars as Track One-and-a-Half mediations. Two aspects of Japan's assistance to Mindanao enabled JICA to engage in peacemaking. First, Japan's assistance to Mindanao formed a unique tripartite cooperation mechanism consisting of the International Monitoring Team, Mindanao Task Force, and Japan-Bangsamoro Initiative for Reconstruction and Development. JICA took part in all three modes of assistance. Second, providing assistance under a volatile cease-fire agreement in Mindanao motivated JICA to become involved in peacemaking outside the traditional function of development assistance.
\end{abstract}

Keywords peacebuilding, peacemaking, human security, ODA, JICA, Track Oneand-a-Half mediation

\section{Introduction}

Japan's search for a role in international peacebuilding as its contribution to international security began after a 13 billion yen financial contribution to the Gulf War (1990-1991) was regarded as mere "checkbook diplomacy" by the international community (Funabashi 1990). Japan turned to its Official Development Assistance (ODA) to promote itself as a peace-loving nation that was willing to share its expertise in supporting development and peaceful resolution of conflicts where needed (Lincoln 1993). The Japan International Cooperation Agency (JICA) - the main implementing body of ODA-actually began taking part in peacebuilding in 1993 during the process of post-conflict rehabilitation and reconstruction of Cambodia, although the term itself was not 
widely used at the time.

In fact, it was only in 2003 that the term peacebuilding was officially used in Japan's ODA Charter, where it was defined as activities throughout the whole process of a conflict, including conflict prevention, emergency humanitarian assistance in conflict situations, assistance in expediting the ending of conflicts, the consolidation of peace, and nation-building in post-conflict situations (MOFA 2003). In the same charter the concept of human security was promoted as a basic policy of Japan's ODA. Japan had been promoting the idea of human security since the late 1990s alongside Canada and other countries, but while Canada interpreted human security in the context of Responsibility to Protect (R2P), Japan emphasized its development facet (Edstrom 2011, 21). As the concept connects peace with development, peacebuilding could be viewed as part of Japan's mode of development assistance (Inada 2004; Shinoda 2003; ContehMorgan 2005).

Yet JICA's role in peacebuilding truly began to evolve in 2006 when efforts were initiated to provide assistance to conflict-affected areas in Mindanao in the southern Philippines. There were three major departures from JICA's practice as a development agency. First, JICA decided to commence assistance under the cease-fire agreement, before a final peace agreement was signed between the Philippine Government (GRP/GPH) ${ }^{1}$ and the Moro Islamic Liberation Front (MILF). It was difficult for a development agency to decide under such volatile circumstances the types of assistance needed in the conflict-affected areas without jeopardizing the status quo between the conflicting parties. Second, JICA was working under tremendous pressure because of the uncertainty of the peace process. However, JICA was aware of key local needs and the security situation in Mindanao, and collaborated extremely well with all parties and agencies involved. This resulted in strong support for the peacebuilding process on the ground. Third, JICA also supported peacemaking efforts by an innovative Track One-anda-Half mediation initiative after the peace process reached a stalemate in October 2008.

This article attempts to answer three major questions about JICA's development assistance in Mindanao: Why did JICA decide to enter Mindanao prior to the conclusion of a proper peace agreement? How did JICA manage its development assistance to maintain a fine balance with the peace process? And, what are the implications of JICA's Track One-and-a-Half mediation attempt in the larger context of Japan's peacebuilding assistance? The article argues that the notion of human security influenced JICA's decision to commence its assistance under the cease-fire agreement. Japan's unique cooperation mechanism in Mindanao also enabled JICA to carry out its assistance in the conflictaffected areas in support of the peace process between MILF and the Philippine government. Moreover, Track One-and-a-Half mediation shows the potential for development agencies to support peacemaking. 


\section{The Mindanao Conflict and the GRP/GPH-MILF Peace Process}

We will touch briefly here on the Mindanao conflict to understand the background of JICA's peacebuilding assistance in that area. The conflict in Mindanao is a typical protracted social conflict (Azar 1990), wherein hostile interactions between identity groups continue over a long period of time with sporadic outbreaks of open warfare fluctuating in frequency and intensity (Azar et al. 1978, 50; Fisher 1997, 79). External (colonial legacy) and domestic (historical and social formation) factors can be identified as primary causes of this kind of conflict. In the case of Mindanao, the legacy of Spanish and American colonization of the Philippines is hard to ignore, as the marginalized and usurped population in Mindanao was left in need of proper recognition of its identity, cultural values, physical security, sufficient livelihood, and equal participation in politics in the modern Philippines (Lingga 2005; Ferrera 2005). Poverty has also been recognized as a cause of conflict. A number of scholars pointed out that the 1968 Jabidah Massacre in Corregidor triggered the armed Moro resistance (Ferrera 2005, 10; Lam 2009, 76) and over the next thirty years the struggle has continued with fluctuations in intensity and frequency of violence as well as with spillovers in issues and actors.

The MILF was born as a factional group within the Moro National Liberation Front (MNLF) just before the first Tripoli Agreement of $1976^{2}$ was signed. MILF's vision for the Bangsamoro armed struggle was (1) the establishment of a true Muslim community, (2) the establishment of a genuine Islamic system of government, and (3) the application of a genuine Islamic way of life in all aspects of society (Mastura 2012). With the conclusion of the GRP-MNLF peace pact in 1996, President Fidel Ramos (1992-1998) started a round of peace talks with the MILF in 1997, but that was just the beginning of a long journey for the peace process.

President Joseph Estrada (1998-2001), the successor of President Ramos, imposed all-out war by the government against the MILF in 2000 and destroyed the previous progress. When President Gloria Macapagal Arroyo (2001-2010) took over from President Estrada in January 2001, she immediately invited the Malaysian government to take up the role of facilitator, and encouraged the MILF to accept the resumption of the peace process. The two parties signed the Tripoli Agreement of Peace on June 22, 2001, which became the formal agreement on pursuing the current peace process. The main agenda for the peace talks included issues related to security, relief and rehabilitation, and ancestral domain (Jubair 2007, 36). The peace negotiations reached a number of agreements, including the agreement on the ceasefire and on the setting up of the Bangsamoro Development Authority (BDA). There was, however, a long impasse in peace talks from September 2006 to early 2008 caused by different views on the issue of 
the territory to comprise the proposed autonomous region (Jubair 2007, 144-147).

Perhaps the most discouraging event was the suspension of signing an agreement on the ancestral domain and the subsequent decision by the Supreme Court of the Philippines in 2008 labeling the agreement unconstitutional. Due to the resulting impasse in the peace process, a number of skirmishes broke out during this period. On June 3, 2010, just before the end of the term of President Arroyo, the peace panels signed a "Declaration of Continuity for Peace Negotiation," which basically re-affirmed consensus points that had already been agreed upon throughout the nine years of negotiations between the two parties during President Arroyo's time.

With the landslide presidential victory of Benigno Aquino, Jr. in June 2010, hopes and expectations were raised among people in Mindanao. However, resumption of peace talks was marked by disagreement over procedural issues of the talks themselves, resulting in a difficult two-year period. Finally a "Framework Agreement on the Bangsamoro" was concluded on October 15, 2012. Both parties agreed to establish an autonomous territory called the Bangsamoro. By late January 2014 substantial issues such as power sharing, wealth sharing, and other remaining matters had been agreed to by both parties prior to finalizing the final peace agreement. On March 27, 2014, the Comprehensive Agreement on the Bangsamoro was finally signed by both the Philippine Government and the MILF.

\section{Japan’s Commitment to Mindanao}

Japan's ODA to Mindanao began in 1989. It was then limited only to nonconflict areas, such as Davao and Cagayan de Oro cities. Changes began after December 2002, when the Japanese government launched a new initiative for the Autonomous Region for Muslim Mindanao (ARMM). A total of US\$40 million was committed for the implementation of the Support Package for the ARMM (MOFA 2002). In 2006, when Japan was invited to join the Malaysia-led International Monitoring Team (IMT) based in Cotabato, then-Japanese Foreign Minister Taro Aso informed President Arroyo of the Japanese government's decision to send a development expert to the IMT, and also conveyed Japan's desire to contribute more actively to the peace process by assisting those living in conflict-affected areas (MOFA 2006). The seriousness of Japan's intent was made clear when Aso also announced that Japan would set up a Mindanao Task Force (hereafter referred to as Task Force) as a mechanism for policy discussion on Japan's assistance to Mindanao (MOFA 2006).

A significant Japanese tool for contributing to the peace process was the Grant Assistance for Grass-roots Human Security Programs (hereafter referred to as Grass-roots Programs) in the conflict-affected areas. This was aimed at 
ensuring that the projects would directly benefit the people at the grassroots level and enable them to experience the dividends of peace, such as through the construction of classrooms, vocational training centers, water supply systems, and health care centers in the conflict-affected MILF areas. The Grass-roots Programs occupied an important position in the Japan-Bangsamoro Initiative for Reconstruction and Development (J-BIRD), the overall framework for Japan's ODA to Mindanao.

\section{JICA's Role and the Concept of Human Security}

After Dr. Sadako Ogata became the president of JICA, in October 2003, JICA mainstreamed human security in all areas of its assistance to address freedom from fear and freedom from want in the forms of bottom-up and top-down approaches. Mindanao became a test case for implementing this concept of human security, and Ogata made concrete commitments when she visited the Philippines in September 2006. Ogata first announced that JICA hoped to make a contribution to the peace process through development assistance under the concept of human security (Manila Shinbun 2006). Then she demonstrated her belief in human security by paying visits not only to President Arroyo and highranking government officials in Manila, but also to the top echelons on the other side of the peace process in Mindanao. She met with Murad Ebrahim, chairman of the MILF, in Sultan Kudarat. The fact that Ogata gave equal importance to both the Philippine Government and the MILF gave all the concerned parties a clear sign of JICA's serious commitment to Mindanao through both top-down and bottom-up approaches. At the end of Ogata's visit it was also announced that Japan would work not only with the Philippine government but also with local communities for the promotion of equitable economic growth and the enhancement of human security (Ogata 2006).

\section{JICA and Japan's Tripartite Cooperation Mechanism}

JICA has been actively involved in all three modes of Japan's assistance to Mindanao, namely the International Monitoring Team, the Task Force, and J-BIRD. This has enabled it to manage its development assistance in a fine balance with the peace process.

\section{Mindanao Task Force}

The first mode of Japan's assistance to Mindanao was the Task Force. The Task Force consisted of the Embassy of Japan in the Philippines, JICA, and (until 2006) the Japan Bank for International Cooperation (JBIC). (JBIC's yen loan operation was integrated into JICA in October 2008, and since then the Task Force has been convened only with the Embassy of Japan and JICA.) The Task Force's mandate 
included the roles of both policy coordinator and also general manager of Japan's assistance to the conflict-affected areas in Mindanao. Chaired by a minister in the Japanese embassy, it met once a month to discuss any matters concerning Japan's assistance in the conflict-affected areas in Mindanao, including the progress of the peace process and Japan's efforts in back-channel diplomacy to accelerate the peace process.

The political role of the Task Force was further strengthened when Japan was nominated to be a member of the International Contact Group (ICG) in July 2009. The ICG monitors the progress of the peace process and advises the Peace Panels. ${ }^{3}$ Japan's membership in the ICG had at least two advantages: First, it became easier for Japan to access first-hand information on the progress of the peace talks, which enabled the Japanese government to take appropriate actions as a peace-builder, if necessary. Second, most of the information obtained by the Japanese delegation, unless absolutely confidential, was shared with JICA by the embassy. JICA's development assistance in the conflict-affected areas has, through this mechanism, been linked to the peace process.

\section{International Monitoring Team}

The IMT was headed by Malaysia and initially was composed of 60 members, including members of the Organization for Islamic Cooperation, Libya, and Brunei Darussalam. Its primary role and responsibilities were (1) to observe and monitor the implementation of cessation of hostilities, as well as the socioeconomic development aspects of the agreements signed between the Philippine government and the MILF, (2) to conduct field verification of any reported violations of the cessation of hostilities agreements, and (3) to report to the Philippine government and MILF Peace Panels its findings and assessment of any violations. Why was Japan asked to join the IMT? First, there was an increasing demand for an expanded peace dividend and not simply for a ceasefire, and thus the IMT's role gradually expanded to include social-economic development issues. ${ }^{4}$ Furthermore, following the establishment of the IMT in 2004, the number of skirmishes had decreased in the conflict-affected area by $90 \%$. Second, there was a demand for Japanese expertise as well as funds in the field of development assistance. Third, ready acceptance of Japan's role by both the Philippine government and the MILF was an important factor (Lam 2009, 82). The development experts dispatched to the IMT were all JICA staff members, and they were seconded to the Japanese foreign ministry and to the Japanese embassy in Manila before being dispatched to the IMT. Masafumi Nagaishi, the first Japanese member of the IMT, conducted the needs assessment which was utilized for the establishment of J-BIRD.

Japan-Bangsamoro Initiative for Reconstruction and Development (J-BIRD) J-BIRD was the third mode of Japan's assistance to Mindanao. J-BIRD started 
in December 2006 with 12 grass-roots programs in Mindanao. Eventually it expanded to include technical cooperation, loan aid, and other relevant modalities of assistance aside from these programs. As of March 22, 2012, the total amount of the assistance was approximately 12 billion yen (Japanese Embassy in the Philippines 2012). The characteristics of J-BIRD can be summarized as follows: First, all assistance projects implemented by the Japanese government and agencies were presented under the all-inclusive J-BIRD scheme. This strengthened the sense of unity and solidarity among the concerned parties. Second, J-BIRD soon became visible and popular in conflict-affected areas in Mindanao. Every infrastructure project assisted by J-BIRD carried its logo on the wall or near the construction site, which became a symbol of good quality and also a dividend of peace. ${ }^{5}$ Third, most of the J-BIRD projects were implemented using a bottom-up approach, including deployment of quick impact projects and on-the-spot assistance. This indicated the general attitude of the Japanese government and JICA towards the conflict-affected areas under a cease-fire agreement, that is to place priority on the empowerment of people and communities, even while the peace negotiation was on-going. Fourth, J-BIRD was well-connected with the socio-economic development needs assessment of the IMT, which was carried out by Japanese members.

On the implementation front, JICA needed to adjust its operational style to the special circumstances under the cease-fire agreement. First, the Bangsamoro Development Authority was designated as a de facto local partner of JICA under the ODA scheme. Since ODA is a governmental development assistance scheme, the counterpart of the Japanese government should, in principle, be the Philippine government. For the Mindanao case, however, the Philippines government approved the involvement of the BDA as a counterpart of donor agencies, including JICA, under authority granted by the government. Second, the fast-track system was introduced to efficiently implement JICA's assistance by early deployment of appropriate aid personnel to field operations and by skipping certain procedures to accelerate decision-making in order to expedite response to the immense needs for assistance. The fast-track system for the conflict-affected areas in Mindanao was approved by the president of JICA on December 28, 2006, and two development study projects have been covered by the system.

\section{Japan's Tripartite Cooperation Mechanism}

The aforementioned functions of the Task Force, IMT, and J-BIRD indicate that there were close interrelated linkages among the three modes of assistance, as shown in Figure 1. JICA took part in all of the three modes of assistance and played a significant role in establishing a tripartite cooperation mechanism by generating synergy among the three functions: peacemaking, peacekeeping, and peacebuilding. First, the IMT and J-BIRD focused on providing a peace dividend, with the socio-economic development needs assessment provided by the Japanese 
Figure 1. Japan’s Tripartite Cooperation Mechanism for Mindanao

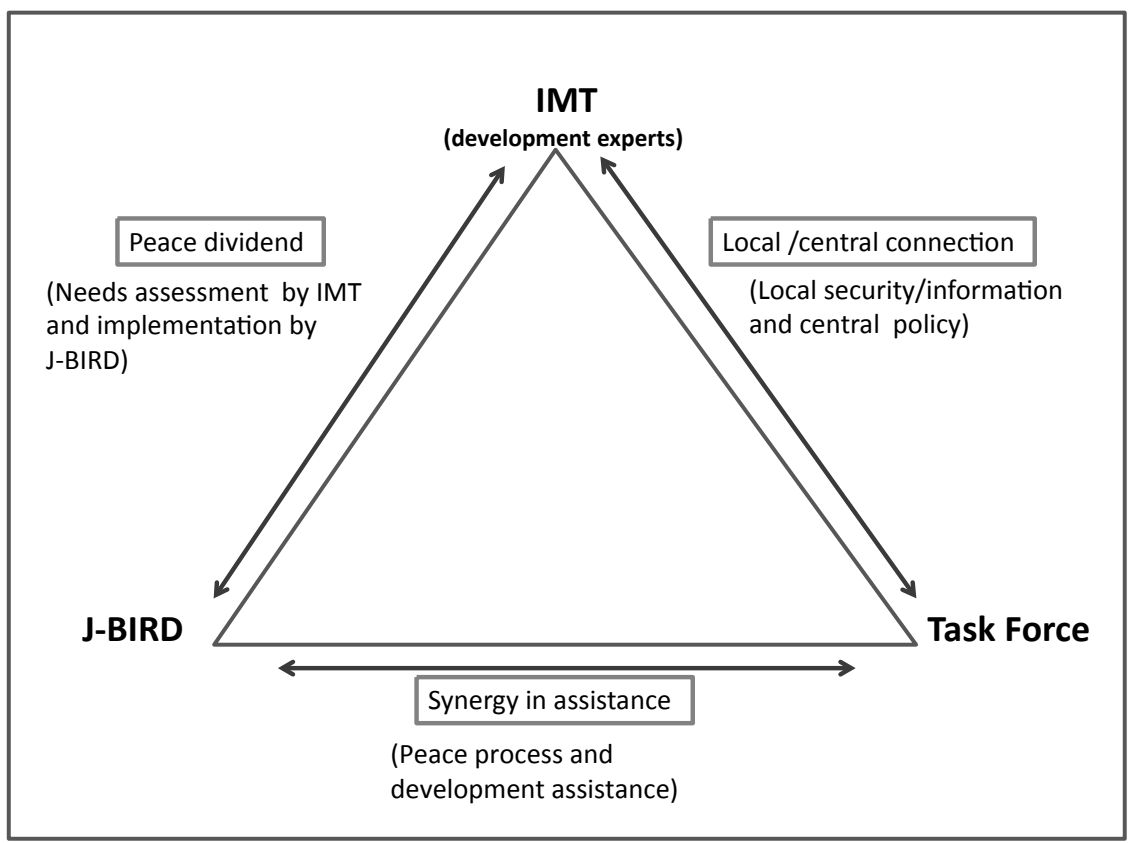

IMT member to be realized by J-BIRD.

Second, the IMT and Task Force strengthened local and central connections in terms of exchanging information as well as by connecting concerned actors between Mindanao and Manila. The Task Force and ICG complemented each other in the sense that through the ICG the consolidated internal views among the Japanese stakeholders in the Task Force could be conveyed to the official peace talks, and at the same time the progress of the peace talks could also be shared with the Task Force. While the Japanese expert on the IMT provided the Task Force with information on local security and other relevant issues, the Task Force disseminated messages and information concerning the peace process to the local communities through the IMT. In Cotabato, for example, a Japanese IMT member frequently contacted MILF peace panel members and local NGOs to maintain good working relationships with the local actors.

Third, there was good synergy between J-BIRD and the Task Force. With first-hand information on the peace process from the Japanese Embassy, JICA's development assistance could be implemented in tandem with the progress of the peace process. The alignment of JICA's development assistance with the progress of the peace process became much smoother after the Japanese Embassy, as a member of the ICG, commenced its function as an official observer. Thus, the aforementioned close relations among the IMT, J-BIRD, and Task Force strongly supported JICA in carrying out its development assistance in balance with the 
peace process.

\section{JICA and Track One-and-a-Half Mediation}

Development assistance in the unstable security situation under the cease-fire agreement gave JICA an opportunity to find an alternative way of contributing to the peace process between the Philippine government and the MILF. When the peace process reached a stalemate, JICA, in collaboration with Malaysian partners, tried Track One-and-a-Half mediation in order to revive the peace process and assist the Track One negotiations.

Security conditions served as a barometer for the progress of the peace talks. When the peace negotiations went well, security issues did not hinder the work of development assistance. However, whenever the peace negotiations reached a stalemate and a tense mood prevailed, a number of armed clashes would take place. In such an insecure situation, development assistance could not continue and aid workers had to evacuate to safer places (JICA 2011, 10-11). If the security situation deteriorated and kept the peace process at a standstill for a considerable time, the threat would emerge that aid programs could be terminated.

For example, after facing insecure conditions with skirmishes in 2007-2009, JICA found it difficult to carry out its assistance in Mindanao. Although the Task Force monitored the peace process and the Japanese Embassy took relevant political actions, these responses were on ad-hoc bases and not part of a coherent government policy. In such a circumstance there emerged views within JICA that the agency needed to change its mind-set in order to provide assistance under the cease-fire agreement. JICA would somehow need to be involved in peacemaking to some extent in order to break the deadlock in the peace process itself.

As Wennmann $(2011,62)$ notes, this echoes a newly emerging perspective that development assistance on its own is insufficient as an incentive for belligerents to suspend hostilities, but it can be an important part of peacemaking if it is placed within a broader political or military context. Wennmann (8990) points out that, in recent years, there has been an ever-growing recognition among development actors that development assistance is not just an economic but also a political process that involves state-building, governance reform, and dispute settlement. In the case of JICA, it gradually began to look at its assistance from such a different perspective and moved forward in playing a more active role in the peace process in Mindanao. Co-organizing a series of the Consolidation for Peace (COP) seminars with the Unit of Research and Education for Peace, Universiti Sains Malaysia in Penang, was its response to this challenge.

Aside from involvement in the Malaysia-led IMT, the COP seminars, in partnership with the university, have been Japan's most visible collaboration with Malaysia (MOFA 2007). To date, Consolidation for Peace Seminars have been 
organized five times as listed below. COP1, COP2, and COP4 were organized for three different conflict areas, namely Mindanao, Aceh, and Southern Thailand, while COP3 and COP5 were designed exclusively for Mindanao.

- COP1: January 23-26, 2006 for Mindanao, Aceh, and Southern Thailand

- COP2: September 2-6, 2007 for Mindanao, Aceh, and Southern Thailand

- COP3: January 12-16, 2009 exclusively for Mindanao

- COP4: February 21-25, 2011 for Mindanao, Aceh, and Southern Thailand

- COP5: January 16-20, 2012 exclusively for Mindanao

The character of the COP seminars gradually shifted from that of fora for mutual learning to Track One-and-a-Half mediations. COP1 offered a mutual learning opportunity for participants from Mindanao with those from Aceh and Southern Thailand. The Mindanawans showed their special interest in the peace process of Aceh, which had been advanced through the Helsinki Peace Accord. COP1 also had a major impact on Japan's commitment to Mindanao. The action agenda adopted at the end of the seminar included two recommendations to Japan: (1) that the Government of Japan join the IMT as civilian monitors in the area of socio-economic development assessment and monitoring, and (2) that JICA engage the BDA as its partner (Askandar and Abubakar 2008, 6). COP1 was the very first opportunity for JICA to contact the actors in the peace process. The representative of the JICA Philippine Office, who attended the seminar, took immediate action by flying to Cotabato to discuss possible collaboration with the BDA. The discussion eventually created a capacity-building training course for the BDA within six months.

$\mathrm{COP} 2$ and COP 4 were also attended by representatives from the three conflict areas. During COP2 and also COP4, the Mindanao and Aceh groups were able to share and benefit from each other's experiences since there were similar dynamics in the two peace processes (Askandar and Abubakar 2008, 8-11). Of particular importance was the fact that both Mohagher Iqbal (chair of the MILF Peace Panel) and Malik Mahmud (former Prime Minister of Aceh Free Movement) participated in COP4, enabling the two leaders to engage in informal discussions on outstanding issues related to the two peace processes.

$\mathrm{COP} 1, \mathrm{COP} 2$, and COP4 were uniquely effective in providing opportunities for engaging in consultations and finding new perspectives and strategies for the different peace processes, and they were certainly appreciated by the participants. However, the impacts created by COP 3 and COP 5 on the Mindanao peace process were greater in the sense that both seminars were organized to address immense needs with the right people and the right agenda. COP3, focused exclusively on Mindanao, was held in January 2009 in Penang five months after the suspension of signing the MOA-AD. When the Supreme Court of the Philippines stamped the MOA-AD as unconstitutional in October 2008, the peace 
process was on the verge of being abolished. All dialogues had been suspended, even informal ones between the antagonists. By the time COP3 was proposed a stark mood of pessimism permeated the civil society actors in Mindanao.

COP3 came at a perfect time when these participants and peace actors sought a platform to meet and discuss the stalemate in the Mindanao peace process. No official Track One negotiators attended COP3 as it was held under the worst circumstances for the peace process. In this sense COP3 took Track Two and Track Three approaches and its main objective became addressing how the civil society groups in Mindanao could contribute to putting the peace process back on track. As its outcome, the group recommended three interconnected processes: resumption of the formal peace talks, consultations at the community level, and sharing of information and advocacy between conflict parties and across stakeholders (Askandar and Abubakar 2009).

It was again good timing when COP5 was organized in Penang in January 2012. It came just one month after the joint statement by the Philippine government and the MILF agreeing to continue their discussions on the substantive points for purposes of crafting a framework agreement. COP5 was marked by its forward-looking agenda on the peace process and by participation by the full range of stakeholders. The range and effectiveness of participation by Track One players was greatly expanded. In addition to the Secretary of the Office of the Presidential Advisor on the Peace Process and both the Philippine government and MILF Peace Panels, other participants included government officials, such as the Secretary of the Department of Interior and Local Government, lawmakers, governors, senators, and congressmen. Other stakeholders in the peace process, including the IMT and ICG, were also invited alongside the ARMM officials and some members of the MNLF, who would be involved in designing the blueprint for a future Bangsamoro entity.

The seminar dealt with specific issues in the peace process, such as forms of governance and political systems, constitutional reform, power sharing, wealth sharing, and post-conflict development. These issues were presented and discussed both in plenary and group working sessions. Although COP5 did not aim at producing concrete answers to the outstanding issues in the peace process, sharing opinions and concerns among the participants from all the levels (including the Track One actors) nevertheless served to revitalize the process. One of the significant effects from COP5 could be seen in the inclusion of the governors of the ARMM in the succeeding Track One peace talks.

Judging from the nature of the seminars and the levels of the participants, it is fair to say that COP 5 could be regarded as Track One-and-a-Half mediation in the current Mindanao peace process. In accordance with Wennmann, mediation is defined as a strategy of conflict management with the aim of shifting the interaction between parties from being authoritarian or adversarial to integrative and problem-solving, which can be located between arbitration and conciliation 
(Wennmann 2011, 6). Moreover, Track One-and-a-Half mediation has been defined as an unusually direct way for unofficial actors to contribute to official peacemaking (Nan 2005, 161).

Track One-and-a-Half mediation brings the strength of Track One mediation-the direct engagement of senior official representatives of the conflict parties-together with the power of Track Two mediation, informal off-therecord workshops on conflict resolution. Track One-and-a-Half mediation can foster a core group with official negotiation skills who can develop personal understandings of and relationships with each other, and also share substantive insights into the conflict issues that divide them (Nan 2005, 161). It should be highlighted that the very strong human network and conceptualization capacity of the Universiti Sains Malaysia were the critical engines that created the COP seminars as Track One-and-a-Half mediations. JICA was a beneficiary of the COP seminars as well as a facilitator, in the sense that JICA gained knowledge of the peace process, expanded its human network in Mindanao, and gathered feedback for J-BIRD.

The impact of the COP seminars on JICA's continuing peacebuilding efforts can be illustrated in three different dimensions. First, JICA's new role in the Mindanao peace process has been articulated and recognized by stakeholders, including the Japanese embassy in the Philippines. The embassy has been supportive of JICA's involvement in the COP seminars because the embassy, as a member of the ICG, is unable to organize such seminars at the Track One-and-aHalf level. Whatever the embassy does in relation to the peace process is regarded as Track One activity, which may cause friction with the Malaysian government as an official facilitator of the peace process. It can be said that the stakeholders' expectations and image regarding JICA has shifted from that of a development agency merely providing economic assistance to a more reliable partner in encouraging local efforts in peacebuilding.

Second, the COP seminars have been a means for JICA to connect the bottom-up approach of its development assistance with the top-down approach of the peace talks in collaboration with its Malaysian partners. As discussed earlier, JICA entered Mindanao under the cease-fire agreement with the aim of promoting the peace process through its development assistance. It has been, however, difficult to influence the Track One actors with a bottom-up approach without a common platform between them. JICA, in alignment with the activities of the Malaysian partners, subsequently discovered the importance of involving Track Two actors, including senators, congressmen, and governors, who had not been included in the ongoing peace process. JICA has learned that it could, in fact, be a good connector between the actors involved in the top-down approach and those working in the bottom-up approach, as John Paul Lederach articulated in a model that he termed Actors and Approaches to Peacebuilding (Lederach 1997, 39). In this sense, it can be said that cooperation with the Malaysian 
Figure 2. Concept of COP Seminars

\begin{tabular}{|l|l|}
\hline Mobilization of Middle-Range Leadership to Connect Top and Grassroots \\
Type of Actors
\end{tabular}

Figure 3. COP Seminar and Japan's Tripartite Cooperation Mechanism for Mindanao

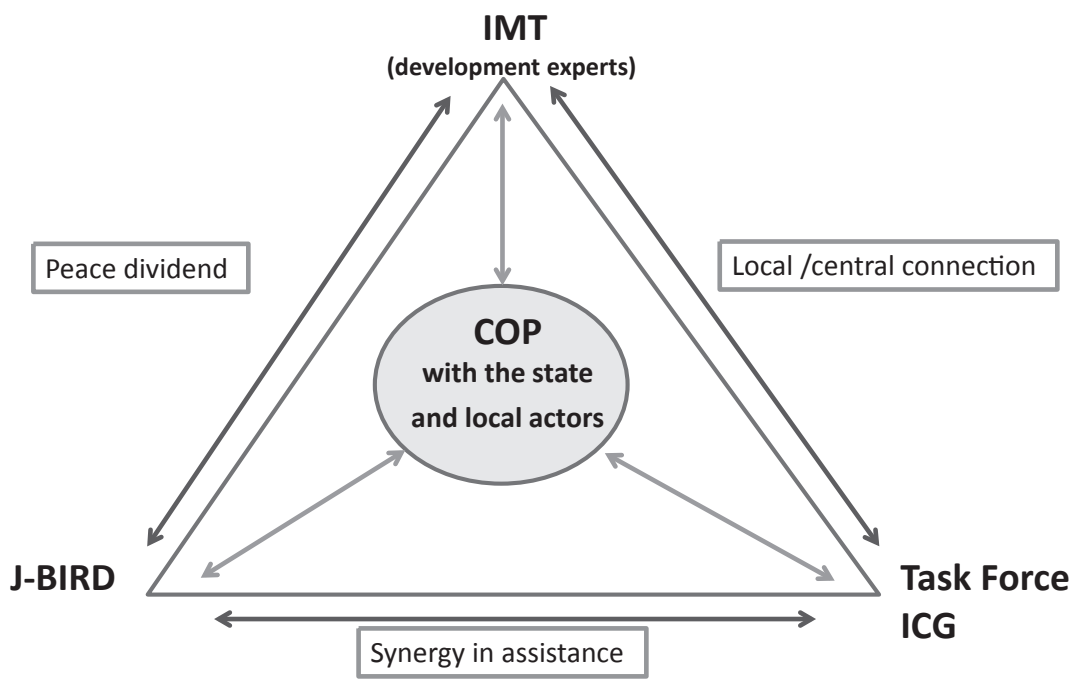


partners enabled JICA to reach out to the middle-range actors, who play the role of connector between the top-down and bottom-up approaches, as shown in Figure 2.

Third, the COP seminars have also had a positive impact on the framework of the aforementioned tripartite cooperation mechanism of Japan in Mindanao. The COP seminars have provided J-BIRD, the development component of the IMT, and the Task Force with feedback from the local seminar participants. In this way Japan's involvement in Mindanao with the three different mechanisms was reviewed and strengthened. Since each COP seminar included development assistance as an agenda item, JICA, alongside Japanese members of the IMT, could exchange ideas and concerns on J-BIRD with the participants and obtain valuable feedback from them. JICA then applied the feedback in its work on the ground. Discussions in the COP seminars were also reported to the Task Force. ${ }^{6}$ It can be said that the COP seminars have been an important feedback mechanism for Japan's assistance to Mindanao and have further strengthened Japan's tripartite cooperation mechanism as shown in Figure 3.

\section{Conclusion}

Japan's commitment to Mindanao has been carried out through a unique tripartite cooperation mechanism. This mechanism has enhanced the effectiveness of Japan's assistance to Mindanao by enabling Japan's participation in peacemaking with the Task Force/ICG, peacekeeping with the IMT, and also peacebuilding through J-BIRD. JICA has been involved in all three modes of assistance, thus enabling JICA to manage development assistance in balance with the peace process. In other words, it can be said that peacebuilding can be carried out more effectively and confidently with the synergetic effect of peacekeeping and peacemaking efforts. Moreover, assistance under the volatile cease-fire agreement has given JICA another dimension to its mission. When the peace process reached a stalemate, it was deemed necessary, as discussed earlier, to connect JICA's assistance on the ground with the bottom-up approach and the political peace process with the top-down approach by mobilizing the middlerange actors as connectors. This measure was indispensable for reactivating the peace process at all levels. In this way the bottom-up approach was secured and even empowered. The partnership with Malaysia enabled JICA to reach out to the middle-range actors. The COP seminars, at the same time, have played a role as the feedback mechanism for Japan's tripartite cooperation mechanism to strengthen the confidence and trust between Japan and local stakeholders in the peace process at all levels. The case of Mindanao echoes the observation that there is a growing recognition in the development community of the potential role of mediation outside its traditional role in conflict resolution (Wennmann 
2011, 94).

Additionally, some lessons have been learned from JICA's experience in Mindanao in terms of peacebuilding assistance with the perspective of peacemaking. First, a development agency is not completely free from the political implications of a peace process, especially if development assistance is commenced before a peace accord is concluded. A development agency accumulates local knowledge and develops trust with local people and communities during its assistance on the ground, which can be of use in peacemaking. Aside from Track Two and Track Three mediations, even Track One-and-a-Half mediation can be carried out if certain conditions are met. Second, and more importantly, close collaboration between peacebuilding and peacemaking should be emphasized. While peacebuilding is mentioned in Japan's ODA Charter of 2003 as a priority area, there is no set governmental policy on peacemaking. As Japan's tripartite cooperation mechanism as well as the COP seminars imply, Japan's peacebuilding assistance could be carried out more effectively in tandem with the government's peacemaking efforts if the Japanese government pays more attention to peacemaking in a systemic way.

The effectiveness of Japan's peacebuilding assistance in southern Thailand and Myanmar will soon be tested. Drawing a lesson from the Mindanao case, Japan's participation in peacemaking efforts is the key to success of its future peacebuilding efforts. In this sense, closer collaboration between Japan's foreign ministry and JICA will be indispensable.

\section{Notes}

1. On October 28, 2010, the Philippine Information Agency released an online report: "DFA Shifts to ISO initials 'ph' and 'phl'” The initials "GRP” will no longer be used. The report of ABS-CBN news read: "DFA junks 'RP', adopts 'PH' or 'PHL.” On November 16, 2010, the Philippine Consulate in New York released to the press, "Philippines ADOPTS ISO 3166-1, from RP to PH.” See, Mindanews. http://www.mindanews.com/mindaviews/ comment/2011/01/22/"grp"-to"gph"-why/ (accessed September 26, 2012). This article therefore uses the "GRP" up to the Arroyo administration in 2010, while the "GPH" is used to address the current Aquino administration onwards.

2. Under the 1976 Tripoli Agreement the Philippine Government and the MNLF reached a compromise agreement to establish an Autonomous Region in the Moro Land. According to the agreement, thirteen provinces out of 25 claimed by the MNLF were to be included in the formation of the Autonomous Government.

3. The Joint Statement of July 29, 2009 was signed by Ambassador Rafael E. Seguis, GRP Panel Chairman, and also by Mohagher Iqbal, MILF Panel Chairman, in the presence of Dato Othman Bin Abdul Razak as Third Party Facilitator.

4. The author's meeting with Brig. General Edgardo M. Gurrea on September 13, 2006 at the office of the GRP Coordinating Committee on the Cessation of Hostilities in Cotabato.

5. The author interviewed Naoyuki Ochiai, an IMT member, on July 14, 2011 in 
Cotabato.

6. The 52nd Task Force meeting on January 27, 2012.

\section{References}

Askandar, Kamarulzaman, and Ayesah Abubakar, eds. 2005. The Mindanao Conflict. Penang: Southeast Asian Conflict Studies Network (SEACSN).

Askandar, Kamarulzaman, and Ayesah Abubakar. 2008. Building Sustainable Peace in Aceh, Mindanao and Southern Thailand: Proceedings of the Consolidation for Peace Seminar 2. Penang: Unit of Research and Education for Peace, Universiti Sains Malaysia and Southeast Asian Conflict Studies Network.

Askandar, Kamarulzaman, and Ayesah Abubakar. 2009. Peace for Mindanao. Penang: Unit of Research and Education for Peace, Universiti Sains Malaysia and Southeast Asian Conflict Studies Network.

Azar, Edward E. 1990. The Management of Protracted Social Conflict: Theory and Cases. Aldershot: Dartmouth.

Azar, Edward E. et al. 1978. "Protracted Social Conflict: Theory and Practice in the Middle East." Journal of Palestine Studies 8 (1): 41-60.

Conteh-Morgan, Earl. 2005. "Peacebuilding and Human Security: A Constructivist Perspective." International Journal of Peace Studies 10 (1): 69-86.

Edstrom, Burt. 2009. Japan and the Challenge of Human Security: The Foundation of a New Policy 1995-2003. Stockholm: Institute for Security and Development Policy.

Fisher, Raymond J. 1997. Interactive Conflict Resolution. New York: Syracuse University Press.

Ferrera, Miriam Coronel. 2005. “The Philippine State and Moro Resistance." In The Mindanao Conflict, eds. Kamarulzaman Askandar and Ayesah Abubakar. Penang: Southeast Asian Conflict Studies Network.

Funabashi, Yoichi. 1990. "Japan and the New World Order." Foreign Affairs 70 (5): 58-74.

Inada, Toichi. 2004. "Kaihatsu fukkou ni okeru ningen no anzen hoshou no igi to genkai" [Purpose and Limit of Human Security in the Context of Development and Reconstruction]. Kokusai Mondai 530 (March): 34-35.

Japanese Embassy in the Philippines. 2012. J-BIRD Information Sheet. March 22.

JICA. 2011. Thematic Guidelines on Peacebuilding Assistance. Tokyo: JICA.

Jubair, Salah. 2007. The Long Road to Peace: Inside the GRP-MILF Peace Process. Davao: Institute of Bangsamoro Studies.

Lam, Peng Er. 2009. Japan's Peace-building Diplomacy in Asia. Oxon: Routledge.

Lederach, John Paul. 1997. Building Peace. Washington, D.C.: United States Institute of Peace.

Lincoln, Edward J. 1993. Japan's New Global Role. Washington, D.C.: Brookings Institution.

Lingga, Abhoud Syed M. 2005. "Mindanao Peace Process: The Need for a New Formula." In The Mindanao Conflict, eds. K. Askandar and A. Abubakar. Penang: The Southeast Asian Conflict Studies Network, 33-50.

Manila Shinbun. 2006. "Heiwa kochiku eno shien hyomei." September 19.

Mastura, Michael. 2012. Bangsamoro Quest: The Birth of the Moro Islamic Liberation Front. Penang: SEACSN \& REPUSM. 
Mindanews. 2011. “GRP' to 'GHP': Why?” January 22. http://www.mindanews.com/ mindaviews/comment/2011/01/22/"grp"-to"gph"-why/ (accessed September 26, 2012).

MOFA. 2002. "Support Package for Peace and Stability in Mindanao." December 4. http:// www.mofa.go.jp/region/asia-paci/philippine/pv0212/mindanao.html (accessed September 8, 2012).

MOFA. 2003. “Japan's Official Development Assistance Charter.” http://www.mofa.go.jp/ policy/oda/reform/revision0308.pdf (accessed February 17, 2011).

MOFA. 2006. "Japan Takes a More Active Role in the Mindanao Peace Process: Dispatch of Japanese Personnel to the International Monitoring Team, etc." June 23. http://www. mofa.go.jp/region/asia-paci/philippine/meet0607.html (accessed February 12, 2007).

MOFA. 2007. "Everlasting Friendship and Far-reaching Partnership: Towards a Common Future." Joint Statement in Conjunction with the 50th Anniversary of Japan-Malaysia Diplomatic Relations. June 24. http://www.mofa.go.jp/region/asia-paci/pmv0708/ joint-4.html (accessed September 8, 2012).

Nan, Susan. 2005. "Track One-and-a-Half Diplomacy: Contribution to Georgian-South Ossetian Peacemaking." In Paving the Way: Contributions of Interactive Conflict Resolution to Peacemaking, ed. R.J. Fisher. Oxford: Lexington Books.

Ogata, Sadako. 2006. "Human Security as a Framework for Peace and Development in Mindanao." Keynote Address for Seminar on Human Security in Mindanao, Heritage Hotel, Manila, September 20.

Shinoda, Hideaki. 2003. "Anzen hoshou gainen no tayouka to hingen no anzen hoshou" [Diversified Concept of Security and Human Security]. In Review of Human Security. Hiroshima: Peace Science Research Center, Hiroshima University, 66-67.

Wennmann, Achim. 2011. The Political Economy of Peacemaking. Abingdon, Oxon: Routledge.

Sachiko Ishikawa is Senior Adviser on peacebuilding and South-South cooperation at the Japan International Cooperation Agency. She worked for the United Nations High Commissioner for Refugees (UNHCR) and Sasakawa Peace Foundation prior to her current post. She received her Ph.D. in Peace Studies from Universiti Sains Malaysia in 2013. Ishikawa has contributed a number of articles related to the issues of Mindanao peacebuilding and ASEAN, including "Japan's Assistance to Mindanao with Human Security Perspective: Is It possible to support Mindanao prior to the Peace Agreement?" in Indigenous Initiatives for Peace Building: Importance of Local Viewpoints and Expected Roles of Development Assistance (2007) and "Towards a People-Centric ASEAN: A Challenge for ASEAN in a New Era” in Harvard Asia Quarterly (2011). E-mail: ishikawa.sachiko@jica.go.jp 
